\title{
Experience of a Preventive Experiment : Spatial Social Mixing in Post-World War II Housing Estates in Helsinki, Finland
}

\section{Vaattovaara, Mari}

Springer

2018

Vaattovaara , M , Joutsiniemi , A , Kortteinen , M , Stjernberg , M \& Kemppainen , T 2018 , Experience of a Preventive Experiment : Spatial Social Mixing in Post-World War II Housing Estates in Helsinki, Finland . in D Baldwin Hess, T Tammaru \& M van Ham (eds), Housing Estates in Europe : Poverty, Ethnic Segregation and Policy Challenges. The Urban Book Series , Springer , Cham , pp. 215-240 . https://doi.org/10.1007/978-3-319-92813-5_10

http://hdl.handle.net/10138/297092

https://doi.org/10.1007/978-3-319-92813-5_10

cc_by

publishedVersion

Downloaded from Helda, University of Helsinki institutional repository.

This is an electronic reprint of the original article.

This reprint may differ from the original in pagination and typographic detail.

Please cite the original version. 


\title{
Chapter 10 \\ Experience of a Preventive Experiment: \\ Spatial Social Mixing in Post-World \\ War II Housing Estates in Helsinki, \\ Finland
}

\author{
Mari Vaattovaara, Anssi Joutsiniemi, Matti Kortteinen, \\ Mats Stjernberg and Teemu Kemppainen
}

\begin{abstract}
The contingent of large housing estates built in the 1960s and 1970s accounts for almost a half of all high-rises in Finland. The primary ideology in their genesis was to combine industrially prefabricated urban housing development with the surrounding forest landscape - together with a policy of spatial social mixingto prevent social disorder and segregation. These policies seemed to work as intended until the early 1990s, but have since proved to be insufficient. With Western integration and new information and communication-based economic growth, new trends of population differentiation have emerged. As new wealth has moved out to the fringes of cities, the large housing estates have declined socio-economically - and have been enriched ethnically. This differentiation is structurally produced, works through the regional housing market and, as such, is beyond the scope of the preventive policies pursued. Recent attempts at controlling the regional markets and new forms of spatial social mixing have so far proved difficult.
\end{abstract}

M. Vaattovaara $(\bowtie) \cdot$ M. Kortteinen · T. Kemppainen

Department of Geosciences and Geography, University of Helsinki,

P.O. Box 64, 00014 Helsinki, Finland

e-mail: mari.vaattovaara@helsinki.fi

M. Kortteinen

e-mail: matti.kortteinen@helsinki.fi

T. Kemppainen

e-mail: teemu.t.kemppainen@helsinki.fi
A. Joutsiniemi
Aalto University, Helsinki, Finland
e-mail: anssi.joutsiniemi@aalto.fi
M. Stjernberg
Nordregio, Stockholm, Sweden
e-mail: mats.stjernberg@ helsinki.fi
(C) The Author(s) 2018
D. B. Hess et al. (eds.), Housing Estates in Europe, The Urban Book Series,
https://doi.org/10.1007/978-3-319-92813-5_10 
Keywords Differentiation - Helsinki, Finland - Large housing estates Local social life $\cdot$ Nordic regime $\cdot$ Preventive policies $\cdot$ Segregation Spatial disintegration $\cdot$ Spatial social mixing

\subsection{Introduction}

The birth of large housing estates in Finland is intrinsically linked to the late and sudden urbanisation of the country. In as late as 1948 , over $50 \%$ of the workforce earned their living from the agriculture and forestry industry, but by 1975, this group had decreased by over 700,000, to about 1,000,000 individuals. Hundreds of thousands migrated - from rural areas in Northern and Eastern Finland - to urban centres in the south, and many also migrated to Sweden. Between 1955 and 1975, about 900,000 new apartments were built, mainly in large high-rises constructed on the outskirts of cities (Hankonen 1994).

Compared to the situation in the rest of Europe, the shift in Finland to urban economic and regional structures emerged particularly late and was both exceptionally sudden and extensive. The national urban and social policies related to this change had several distinctive characteristics, as do the public structures through which the changes were managed, factors which are clearly reflected in their resultant urban structures.

\subsection{Planning and Construction}

Compared to many other countries, municipalities in Finland enjoy an exceptionally large degree of autonomy. The reasons for this are largely historical: the strong and independent peasantry was the main social and political agent in the early twentieth century, and municipal self-determination was inserted into the constitution for this reason. As a result, municipalities in Finland have an autonomous right to levy taxes (i.e. they have their own revenue base) and significant legal obligations to provide social, healthcare and educational services for their residents. The decision-makers are chosen in local elections. Residential planning, too, is controlled by the municipalities and since 1932 they have had a monopoly over all aspects of planning, giving them the sole right to dictate all land use, including privately owned land (Puustinen 2006).

In the post-war Finland of the 1950s architect-led discourse dominated in community planning, and since 1999 there has even been a national register of qualified planners (Puustinen 2006). Architects following this national tradition see themselves as pursuing a 'common good', fighting against the private interests that prevail in the market. This concept has varied somewhat over time, and in the 1960s 
and 1970s, planning discourse was dominated by a particular sociopolitical perspective: 'Common good was now about "equal good for everyone" (Puustinen 2006, p. 168). Also, the new goal of planning was to reduce social inequality. Through this, the urban policies pursued were a part of a larger political project that ended in the construction of the Finnish version of a Nordic Welfare State.

Ever since the first national Planning Act (Asemakaavalaki) of 1931, all planning activity in Finland has been considered municipal activity, with the exclusion of private planning. Initially, this pertained only to urban agglomerations but was later extended to cover all land use. This has also given Finnish planning a specific focus on the 'common good' and the public sector as a whole.

The Building Act of 1959 obligated municipalities to build infrastructure. The massive migration and related growth had created an immense financial burden on municipalities, in a country that was still, by European standards, rather poor. The structure of the public sector together with the national legislation presented above created a situation that had a profound influence on the urban structures thus ensuing.

Municipalities could only meet the challenge they faced through allying with private construction companies in a quite peculiar way. The solution was called 'neighbourhood construction procedure' The municipality agreed to allocate a specific piece of land for the construction of a certain amount of floor space, and the property developer agreed to pay for the right to build and sell houses on it. At the same time, the developer also agreed to construct and pay for the municipal infrastructure needed for the area.

The financial logic from the perspective of the municipality was simple: the more floor space the municipality designated to be constructed on a given piece of land, the more money it could ask for it from the developer. The cheaper the land originally, the greater was the increase in its value. This gave the municipalities a chance to profit from planning, thanks to the monopoly they enjoyed; the most cost-effective projects were achieved by having a lot of floor space built on inexpensive and remote land in order to maximise the increase in its value. On the private side, the appeal of the deal lay obviously in the allocated floor space that could be sold. It was therefore easy to reach a compromise: the greater the floor space the municipality designated for a given site, the higher the price asked for it, as the construction company would have more floor space to sell.

This resulted in a peculiar urban structure, typical in the Helsinki Region but also in other major cities in Finland: The proportion of large housing estates built in the 1960s and 1970s is notably high (Fig. 10.1), compared to any other housing type. Furthermore, the large high-rise suburbs tend to be scattered here and there - in the middle of forests and fields that isolate them from the existing urban fabric (Fig. 10.5). 


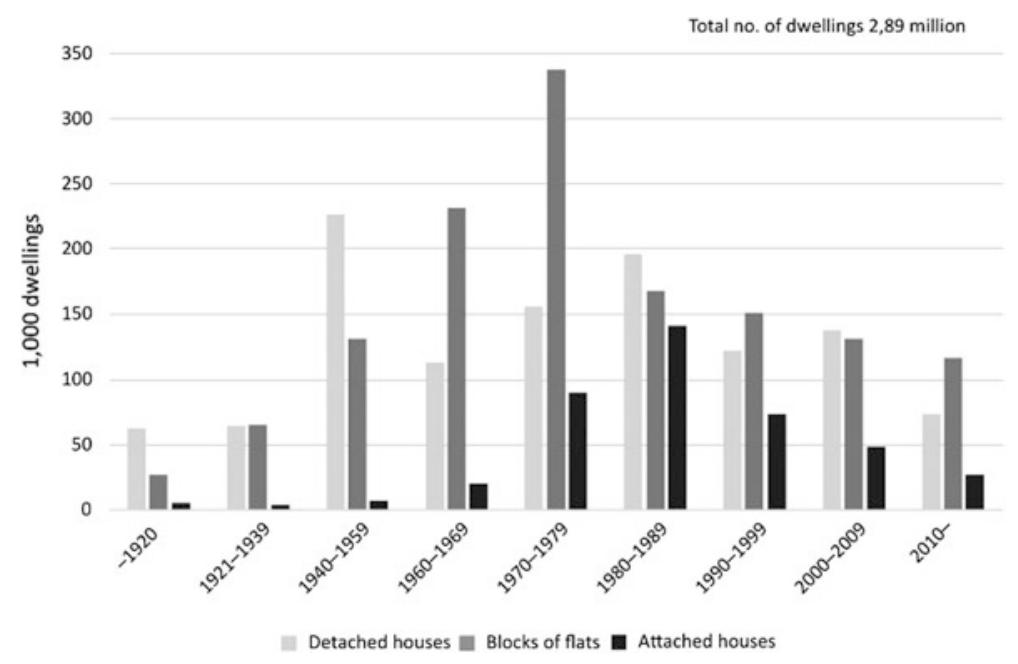

Fig. 10.1 Number and type of dwellings constructed by decade in Finland. Source Statistics Finland 2017

\subsection{National Interpretations of Planning Ideologies}

Tapiola Garden City, established in 1951, served as the model for Finnish new town development. The central ideology was to combine industrially prefabricated urban housing development with the surrounding forest landscape, a concept that quickly acquired international reputation and still serves as an iconic example of Finnish urban planning. The concept became somewhat more streamlined and brutal during the main construction period of suburban fringe in the 1960s and 1970s, although the social ideology survived for a surprisingly long time (the idea of a public library in every suburb, for example) (Fig. 10.2).

It is common in Finnish textbooks to claim that this national style of decentralisation was carried out in accordance with the so-called 'neighbourhood scheme', usually attributed to Clarence Perry and Clarence Stein (Perry 1929; Stein 1942). The original neighbourhood ideology of Perry and Stein was, however, adopted in a very piecemeal manner and was merged with national policies concerning main roads and arterial roads. This dominant model of road building was taken from the parkway typology of the USA, where the road was surrounded by unbuilt nature (Meurman 1947). Although the roadside landscape hardly meets the criteria of what we traditionally mean by a park, it became a success as it also provided a means to reduce the number of road intersections, thus supporting the two grand ideals of traffic planning - traffic separation and free traffic flow.

This amalgamation is best seen in the iconic 'Neighbourhood Unit Plan' (below on the left) and the 'Plan of a Decentralised Town' (below on the right) by Prof. Olli Kivinen in his Hämeenlinna town plan (Kivinen 1959, pp. 19-20) (Fig. 10.3). 


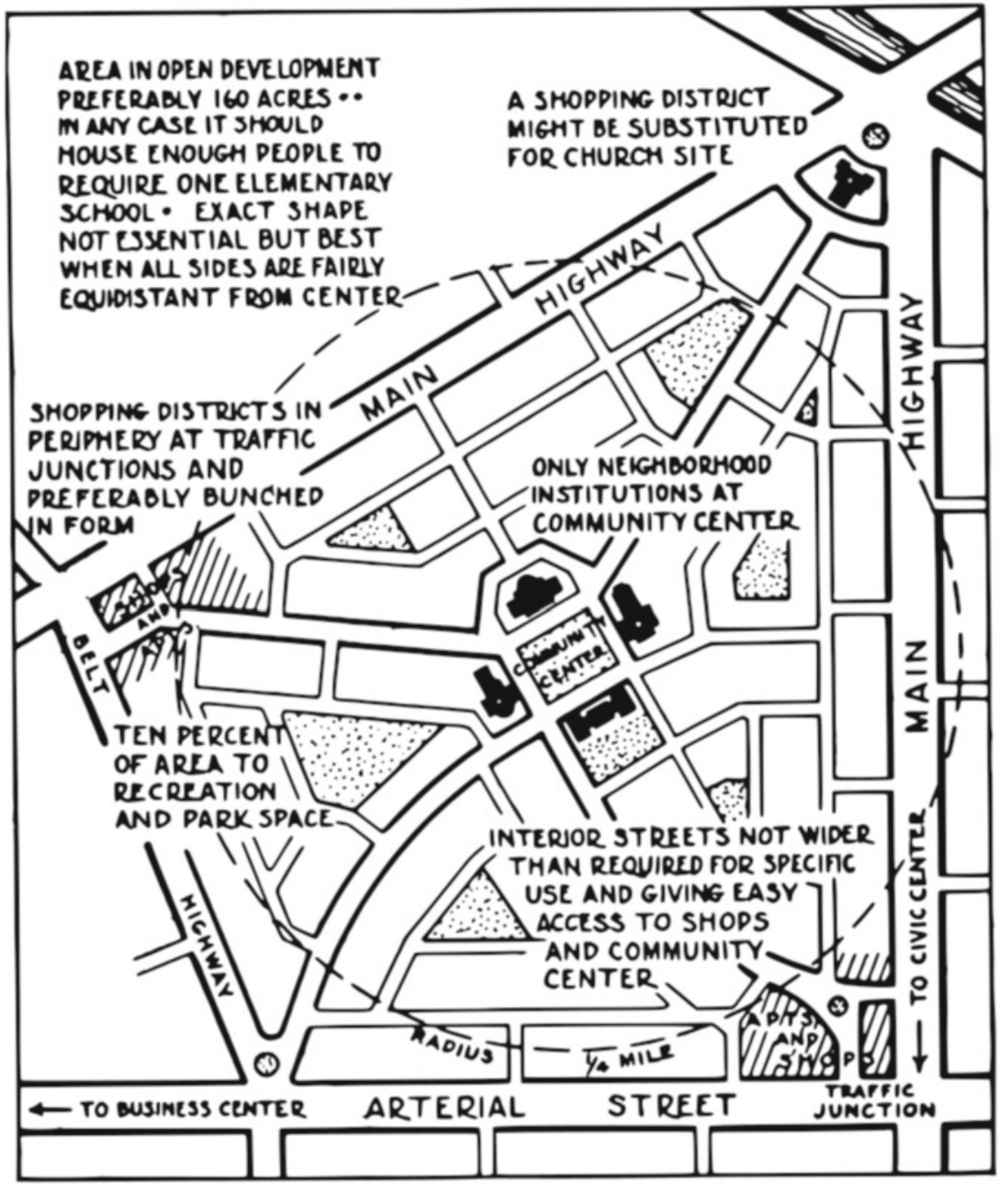

Fig. 10.2 Concept for a planned neighbourhood (after Perry 1929)

It is not difficult, however, to see differences between the original sources and the Finnish 'lung model', as it was later called. The transportation network was created following a strict hierarchical tree pattern, which divided activities into separate fixed-sized units with minimal interaction outside the neighbourhood units. In Perry's scheme, the shopping facilities are located along the main arteries for optimal accessibility. The schematic representation by Perry is misleading and led to oversimplified solutions - a mistake that became obvious later when new layers of commercial activities appeared from the 1990s onwards. Closer analysis shows that Perry's scheme and its further derivation by Stein are based in built-up areas 

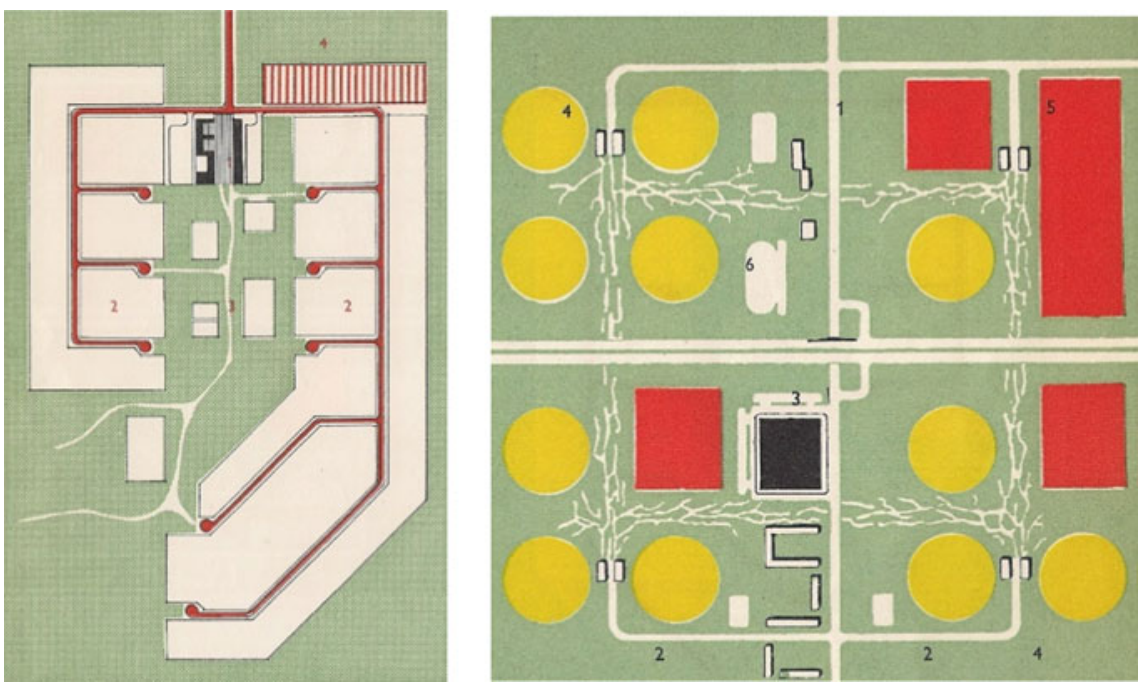

Fig. 10.3 Neighbourhood unit plan (left) and plan of decentralised town (right) by Olli Kivinen

where neighbourhoods seamlessly continue over arterial roads, making the model flexible for the increase and overlap of multiple centrality needs - hardly the case in the Finnish implementation. Perry's model was a part of the continuous urban fabric of New York, while the Finnish model deliberately separates the housing units from the large urban whole.

A new layer of commercial activities also came into being on the suburban fringe from the 1980s onwards. This new logic of large-scale shopping centres and municipal level sub-centre development did not follow the logic of earlier suburban neighbourhoods but built new indoor shopping centres in-between the existing scattered suburban fabric. In the following images, it is easy to recognise how smaller suburban sub-centres were reconnected with new larger shopping centres. The new locations are mainly those with excellent access for private cars and a concentration of public transport routes. This also led to the decline of the original commercial centres of older suburbs, now mainly hosting local pubs, small shops and occasional one-person companies (Figs. 10.4 and 10.5).

Nevertheless, it must be appreciated that the housing policy in Helsinki also had a socio-political dimension, at the core of which was the idea of spatial social mixing. Its historical starting point was the Siilitie riot of 1961, in which young people from a large area of rented housing started to riot and to fight with police (see Schulman 2000). The incident resulted in an emergency meeting of the Helsinki city administration. The solution was to scatter municipal rental housing amongst other types of housing, thereby preventing the formation of large areas with primarily rented flats. With one exception, the policy has been consistently pursued since then. 

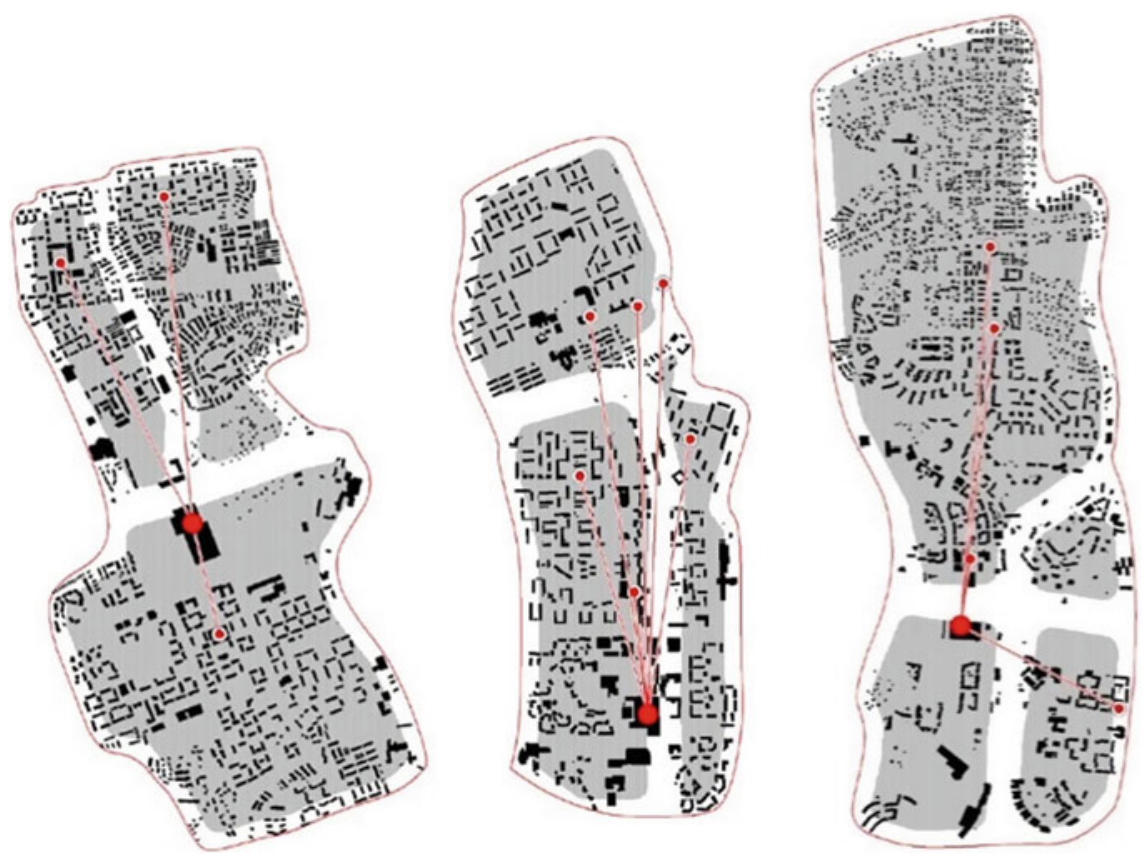

Fig. 10.4 Reconfiguration of neighbourhood-level shopping activity in Matinkylä, Myyrmäki and Leppävaara sub-centres in greater Helsinki region. (Joutsiniemi 2006, p. 45)

Spatial social mixing was initially practised at the residential block level, i.e. using blocks as the units to be mixed. This led large rented housing units, the size of relatively massive blocks, to clearly separate from the rest of the neighbourhood and with hundreds of residents. The policy was revised in the mid-1970s when the decision was made to use buildings instead of blocks as the units for mixing. Since the 1970s, the policy has been to construct blocks with architecturally identical buildings but with many types of tenure. In one particular case (Ruoholahti in the 1990s), tenure mixing was extended inside the buildings. The political argumentation changed, too: since the 1960s, there has been no more talk of social order (cf. the case of Siilitie), but rather of equality - the aim being to produce an urban structure in which everyone lives together in the same reality.

This policy of mixing was implemented strictly and consistently in projects in Helsinki and, in the 1970s, it spread to the adjacent towns of Espoo and Vantaa, covering the whole of the metropolitan area.

This caused the Helsinki Region to become quite exceptional by international standards, not only spatially but also socio-economically. As late as in the late 1980s and early 1990s, differences in income between sub-districts were small (the relationship of incomes in the richest and the poorest sub-districts was the same in 1994 as it had been in 1980). This was also the case with regard to unemployment 


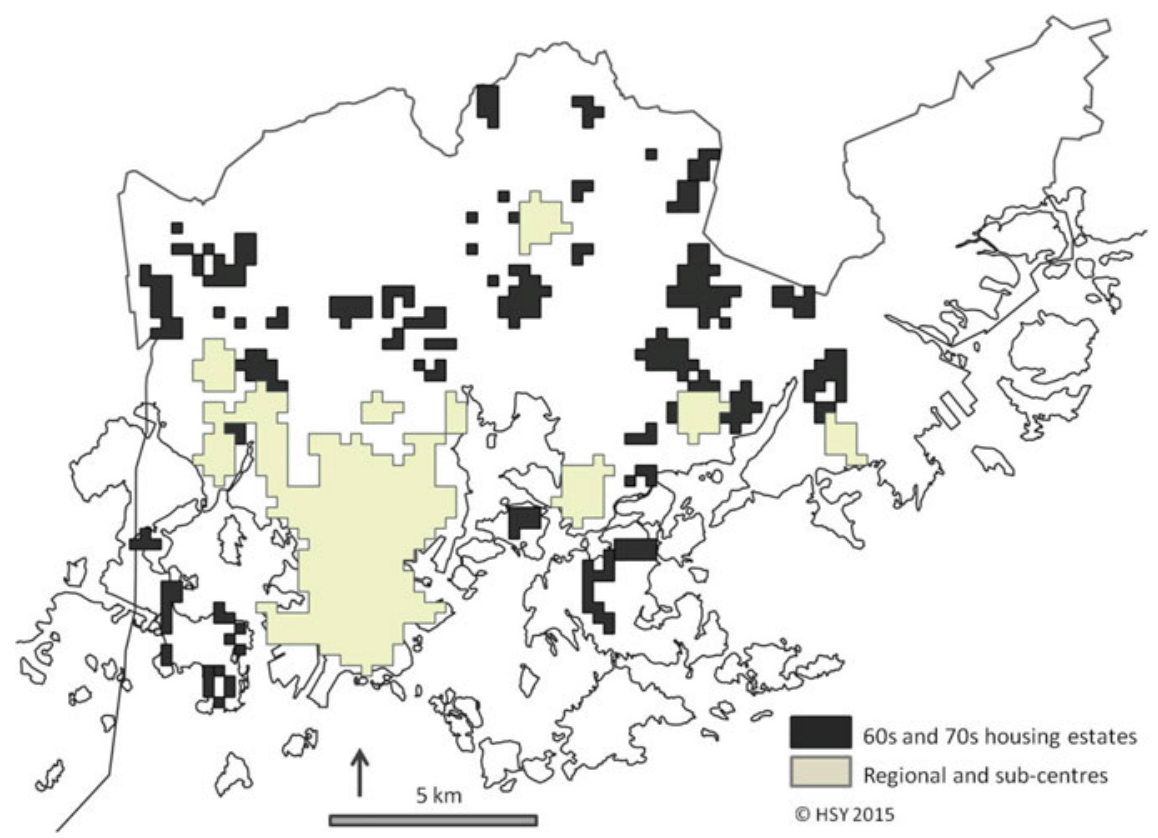

Fig. 10.5 Locations of 1960s and 1970s housing estates in Helsinki

(in 1989, the lowest unemployment rate was $0.1 \%$ and the highest $2.1 \%$ ) (Vaattovaara and Kortteinen 2003). In addition, the areas built after 1960 are each internally heterogeneous, i.e. each has its own so-called 'social apartment base', at the level of either blocks or buildings, scattered inside the area. The outcome of these factors was an urban structure that is, to the best of our knowledge, unlike any other in the world, with deprivation spread across the region in a mosaic-like pattern (Vaattovaara 1998).

As Finland opened up more towards the West in the early 1990s, and the USSR collapsed, the country was hit by the deepest depression among the OECD countries. This quickly had a profound effect on urban development: unemployment quickly reached exceptionally high levels (with about one-third of the workforce being unemployed in some sub-districts of Helsinki). The depression was followed by a strong information and communication-based upswing, based around Nokia, which started in 1994. Through this, the demand for labour moved towards professions requiring a high level of education, while the demand for unskilled labour diminished drastically (see Vaattovaara and Kortteinen 2003). This gives an opportunity to study how spatial social mixing, designed to be preemptive, works under conditions of rapid socio-economic and also ethnic differentiation. 


\subsection{Socio-Economic and Demographic Change Since the Early 1990s}

The information and communication-based economic growth that had begun in 1994 gave rise to a growing multi-municipal metropolis in the Helsinki Region. The commuting area grew fast to extend first to the neighbouring communities of Espoo and Vantaa and later also the so-called 'ring municipalities': 14 municipalities surrounding the metropolitan area consisting of the three major cities. The result was a single metropolitan district consisting of nearly 20 different municipalities.

All municipalities independently control the planning and construction within their region. However, in a multi-municipal commuting area inter-municipal competition emerges, not only of firms but also of residents. This is based on the structure of public governance in Finland, in which a municipal economy is based on municipal tax revenue, the majority of which comes from the salaries of wage-earners. As the municipalities are responsible for the provision of public services to their residents, and the subsequent expenses are largely towards services in social welfare and health, this setting creates the basis of municipal competition for the working, tax-paying population that produces more public revenue than it spends. The rapid ageing of the population adds specific intensity to this competition.

Helsinki has predominantly produced dense, high-rise and mixed urban constructions, mainly large housing estates, along the main railway lines. Both social and ecological considerations have are at play in this - it is a way to combine affordable housing and sustainable development. As the neighbouring, traditionally rural, municipalities have relied more on the production of detached housing, the quality of housing supply varies across municipalities.

The new information and communication-based growth of the 1990s led to significant growth of wealth in the region. This, together with an overall downward trend in the real price of housing relative to real wages (see Lönnqvist and Vaattovaara 2004), resulted in a situation in which people (especially the wealthier ones) could afford bigger and/or better housing. All surveys regarding housing demand show that this results in the growth of demand for detached housing, preferably in peaceful settings close to nature (Vaattovaara and Kortteinen 2003).

As a result, new spatial differentiation has emerged, with two distinct facets: new wealth moves out to the growing belt of detached housing surrounding the previously built large estates, and these, at the same time, start to decline socio-economically, and their ethnic diversity starts to grow.

As a starting point, there is the dispersed, mosaic-like structure based on the policies of mixing. A spatial description based on small GIS units, the size of a block ( 250 by $250 \mathrm{~m}$ ) is the most suitable basis to describe the spatial structure (see Fig. 10.6). The attached maps (Figs. 10.6, 10.7 and 10.8) show the GIS squares that are in the lowest quintile in education, employment and income in 1990, 2000 and 2010. Both the number and size of these pockets of poverty have grown, and new ones have emerged in the immediate vicinity of the old ones. As development has 
continued over the last 20 years, larger spatial units have formed, predominantly in the eastern part of Helsinki.

The development has affected the relative position of the large housing estates in the region, especially that of housing estates built in the 1960s and 1970s (see Table 10.1). In 1990, most suburban housing estates were largely similar to their wider subregion in terms of unemployment and level of income, in Finland as a whole and within the Helsinki Region. In terms of education, however, housing estates, already had a lower proportion of people with tertiary education. As the demand for labour turned towards professions requiring tertiary education, a clear downward socio-economic trend appeared. In 2010, housing estates were also in a weaker socio-economic position in terms of unemployment rate and income. In other words, the large housing estates in the region started their socio-economic decline in the early 1990s, and not before.

The median unemployment rate among the 48 housing estates increased from 1.8 to $12.5 \%$ between 1990 and 2013, while unemployment in the whole of Helsinki grew from 2.0 to $10.0 \%$. The most significant changes in unemployment occurred during the 1990s in the aftermath of the recession, but unemployment peaked again between 2010 and 2013 during a new economic downturn. The same trend applied to levels of income and education, and to the ageing of the population: all these features have developed unfavourably, especially on the large housing estates.

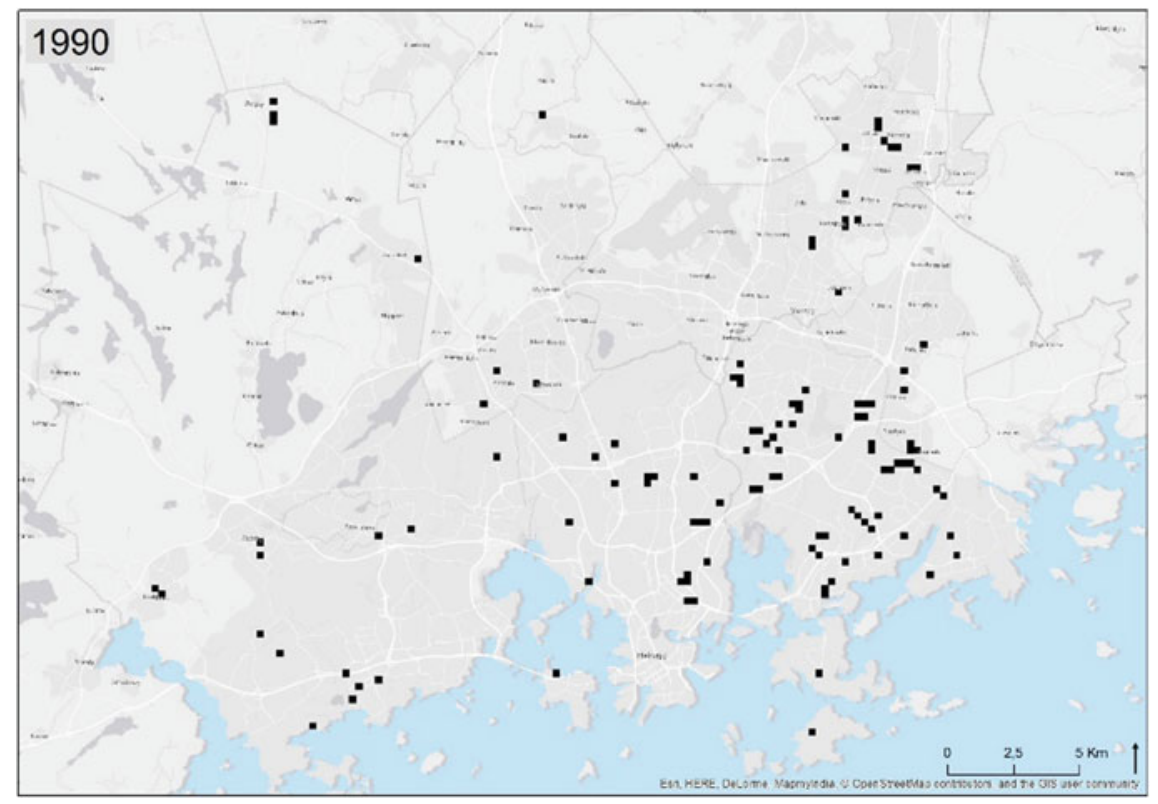

Fig. 10.6 Distribution of the lowest spatial quintile units (measuring education, employment and income), 1990 


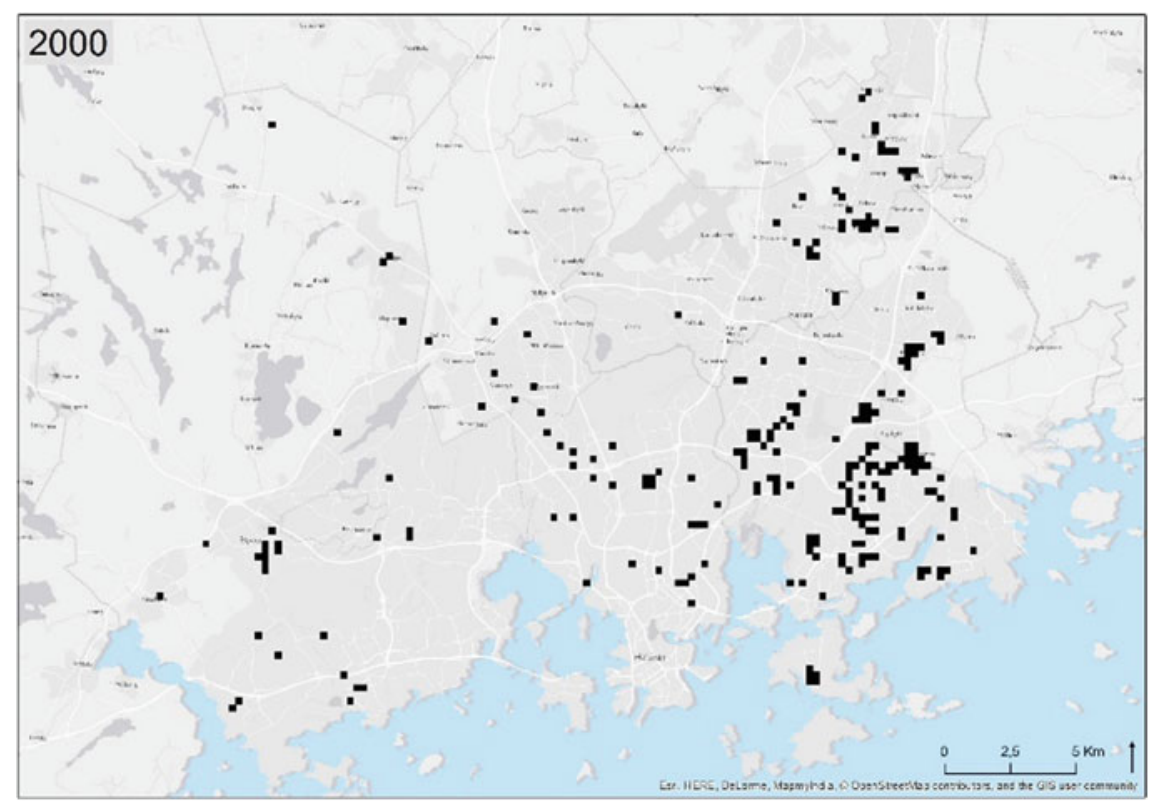

Fig. 10.7 Distribution of the lowest spatial quintile units (measuring education, employment and income), 2000

These 48 estates had a total population of 115,090 in 2014 , meaning that approximately $19 \%$ of the total population in Helsinki lived in these specific estates (Table 10.2). In 1990, 124,823 people lived in these housing estates that formed around $25 \%$ of the city's population. These housing estates are quite heterogeneous in terms of their internal characteristics. Figure 10.2 shows that there are noticeable differences in their overall size, illustrated by substantial variation in population size and the number of dwellings. For instance, whereas the median population size in these estates in 2014 was 1,306, eight estates had populations greater than 5,000, and 11 estates had populations lower than 500. There are also clear differences in terms of housing tenure, which is exemplified by the fact that some estates were clearly dominated by renter-occupied housing (over $80 \%$ in three estates), whereas others had substantial proportions of owner-occupied housing (over 60\% in nine estates) (Figs. 10.9 and 10.10).

It further seems that the unfavourable development of the large housing estates is closely related to housing tenure - despite the continuation of policies of spatial social mixing. In Table 10.2, housing estates have been divided into quartiles according to the proportion of socially rented housing on each estate. Housing estates with above-average numbers of socially rented housing are socio-economically the most disadvantaged. The same correlation is also true with the level of immigrant population. Generally speaking, estates with high proportions of socially rented housing have substantially higher numbers of residents with 


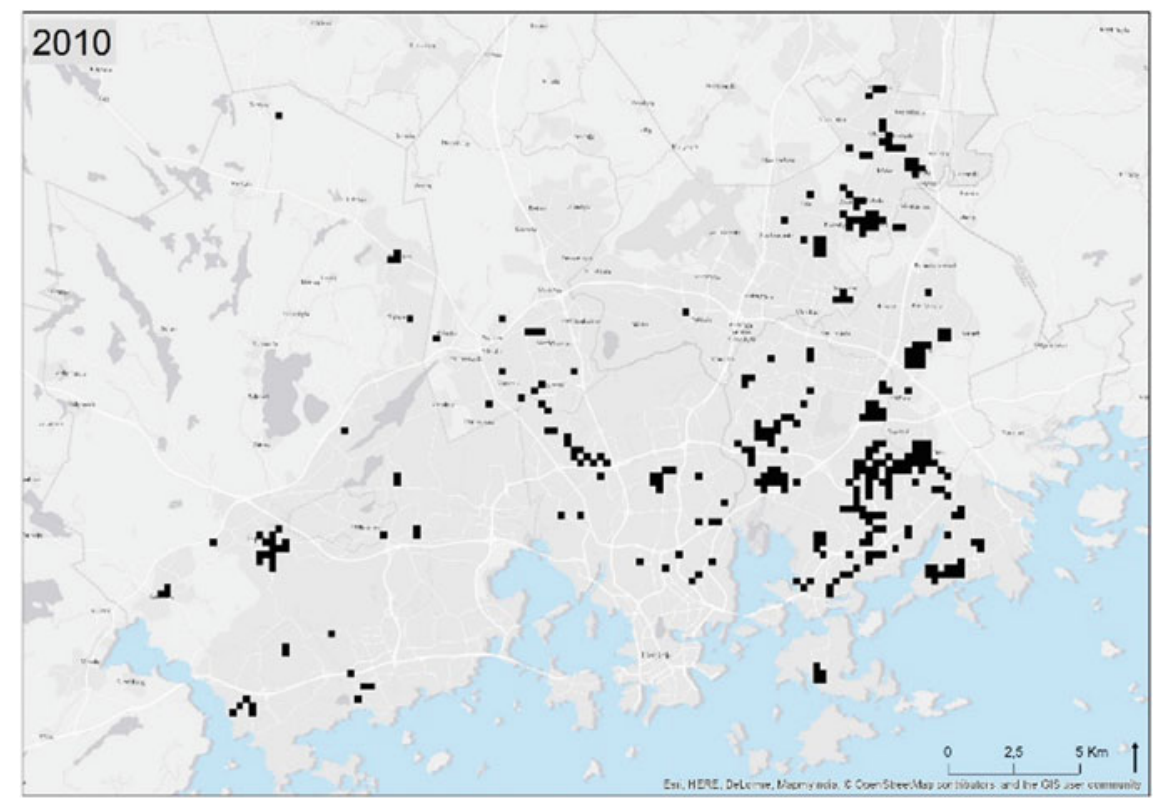

Fig. 10.8 Distribution of the lowest spatial quintile units (measuring education, employment and income), 2010

a language other than Finnish or Swedish as their first language, indicating that people with immigrant backgrounds have often settled where social housing is common (Table 10.3).

A separate analysis on the development of the estates illustrates significant changes both in unemployment and in the proportion of ethnic minorities between 1990 and 2013. Initially, both unemployment and immigrant population were virtually non-existent, but in both cases, the differentiation amongst the estates has become increased substantially. The development has concentrated on the estates with larger than average proportions of social rental housing, especially on the eastern parts of Helsinki and along the main railway line to the north-in other words, into the areas that originally had lower than average levels of education and income.

In summation, it seems that the major shift in the demand for labour has produced a socio-economic decline in populations with lower than average levels of education and that this decline has spatially affected the large housing estates in which these populations originally settled. These are the estates farthest from the centre, in the northeast and east of Helsinki. The immigrant population tends to concentrate specifically in these areas. 

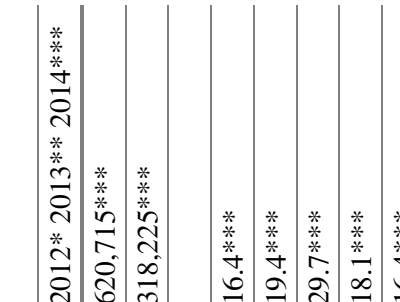

$\mid$

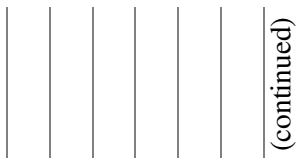

ז̂

ナ. $\neg-\forall$

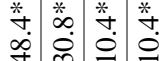

苟

$-2 \therefore 0$

-

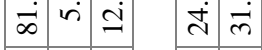

趈

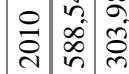

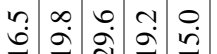

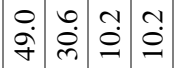

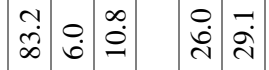

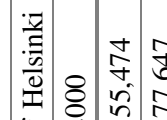

น

Iุ

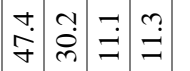

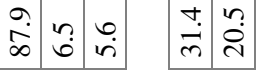

高

8 으

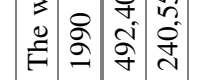

I.

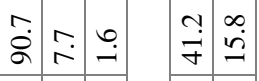

究

*

$\stackrel{*}{*}$

호

蒡

호 *

$\cong$

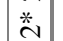

글

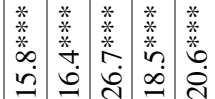

草

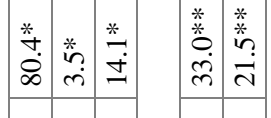

$\begin{array}{cccc}\stackrel{\infty}{+} & 0 & \vec{n} & n \\ \text { II } & \stackrel{n}{n} & n & n\end{array}$

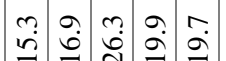

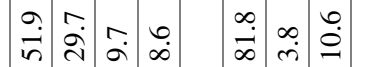

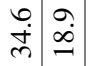

营 $\exists$

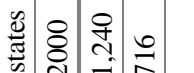

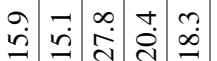

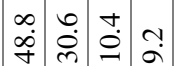

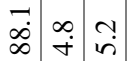

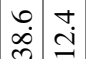

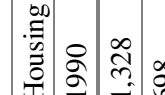

$\ln \frac{\pi}{2}$

๓ฺ

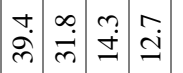

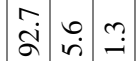

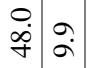

可

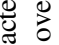

突 공

ธี ํㅗ

홀 옹

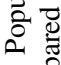

홍 छे

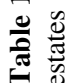

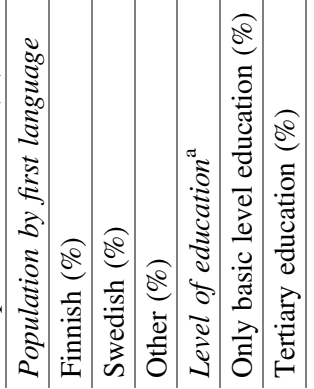




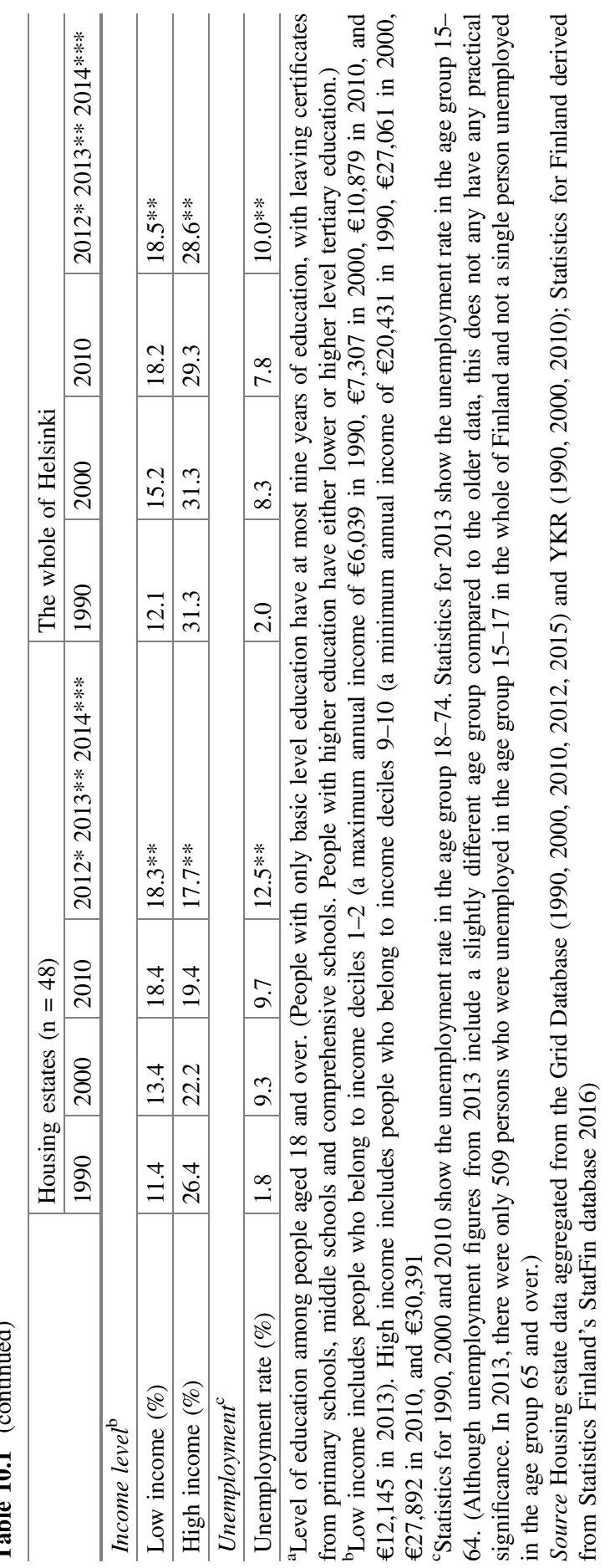


Table 10.2 Total population and share of population in Helsinki's 1960s and 1970s housing estates in 1990, 2000, 2010 and 2014

\begin{tabular}{l|l|l|l}
\hline & Housing estates $(\mathrm{n}=48)$ & Helsinki & $\begin{array}{l}\text { Share of Helsinki's } \\
\text { population in housing } \\
\text { estates }(\%)\end{array}$ \\
\hline Total population 1990 & 124,823 & 492,400 & 25 \\
\hline Total population 2000 & 114,944 & 555,474 & 21 \\
\hline Total population 2010 & 112,494 & 588,549 & 19 \\
\hline Total population 2014 & 115,090 & 620,715 & 19 \\
\hline
\end{tabular}

Number of inhabitants

in housing estates (2014)

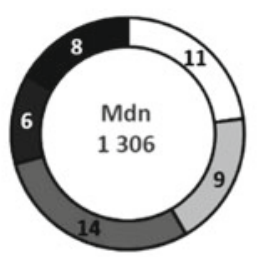

-499

口500-999

Share of owner-occupied dwellings

in housing estates (2010)

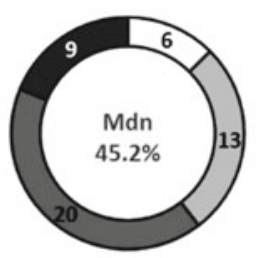

口0-19\% 口20-39\% व $40-59 \%$

\section{Number of dwellings}

in housing estates (2014)

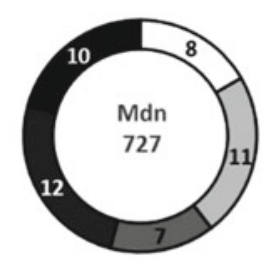

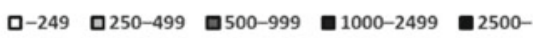

Share of renter-occupied dwellings in housing estates (2010)

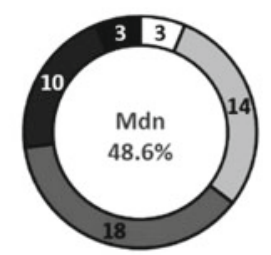

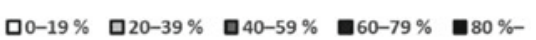

Fig. 10.9 Number of inhabitants and dwellings, as well as tenure structure of housing estates in Helsinki $(n=48)$ (Numbers inside the graphs show number of housing estates that belong to each category and median share among all estates)

\subsection{Local Social Life in Helsinki Housing Estates}

It is worth noting that the decline of the eastern part of the Helsinki metropolitan area has been gradual and mainly relative in nature. In the conditions caused by the upswing of the 1990s, unemployment diminished, and incomes still grew in the 
Share of foreign-language speakers

in housing estates (2012)

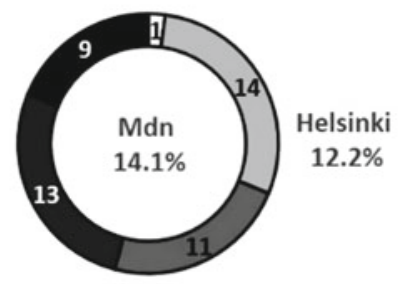

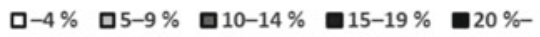

Share of low-income earners

in housing estates (2013)

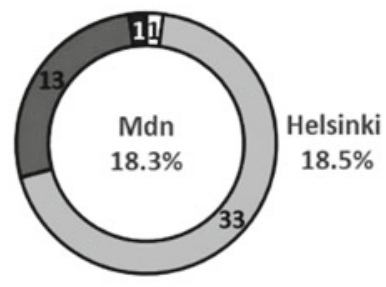

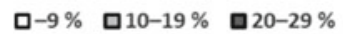

$30-39 \%$

$40 \%-$

\section{Share with only basic level education} in housing estates (2013)

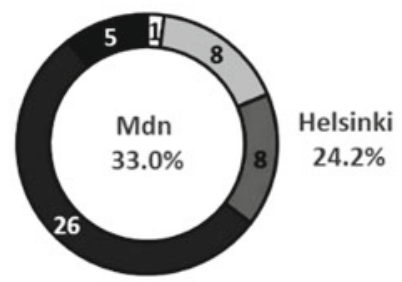

\section{Unemployment rate}

in housing estates (2013)

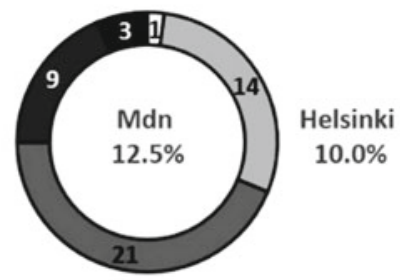

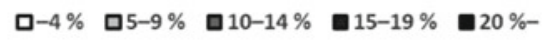

Share of high-income earners
in housing estates (2013)

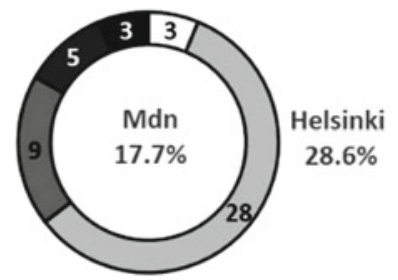

口10-19\% ㅁ20-29\%

$40 \%-$

\section{Share with tertiary education \\ in housing estates (2013)}

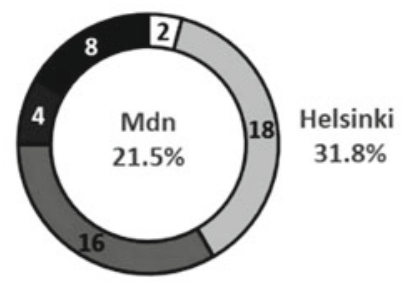

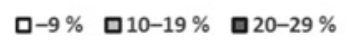

$30-39 \%$

$40 \%-$

口-9\%

口10-19\% प $20-29 \%$

$30-39 \%$

$40 \%-$

Fig. 10.10 Ethnic and socio-economic structure of housing estates in Helsinki $(n=48)$ (Values inside the figures show number of housing estates that belong to each category and median shares among all estates as well as the respective share for the whole city)

east, only the pace of the upswing was somewhat slower than elsewhere. Undeniable impoverishment, however, has also emerged. As a spatial phenomenon, long-term unemployment did not exist in housing estates before the 1990s. The number of long-term unemployed in the research area was 1,400 , comprising $0.2 \%$ 


\begin{tabular}{|c|c|c|c|c|c|c|c|c|c|c|c|c|c|}
\hline 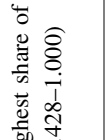 & 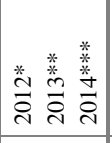 & : & 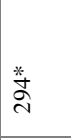 & & 䔲 & 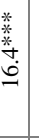 & 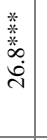 & & & $\begin{array}{l}\text { 䖭 } \\
\text { 字 }\end{array}$ & 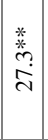 & $\stackrel{\text { * }}{\text { : }}$ & $\begin{array}{l}* \\
* \\
2 \\
0 \\
0\end{array}$ \\
\hline 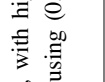 & 음 & : & 令 & & $\hat{\dot{i}}$ & $\stackrel{9}{\Xi}$ & चूं & $\overrightarrow{\mathrm{i}}$ & $\dot{I}$ & $\hat{b}$ & $\begin{array}{c}\dot{a} \\
\dot{d} \\
i\end{array}$ & $\stackrel{ \pm}{\mathrm{I}}$ & $\overline{\mathrm{I}}$ \\
\hline 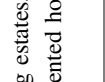 & ¿্ণ & $\vec{G}$ & $\begin{array}{l}\infty \\
\infty \\
i \\
i\end{array}$ & & 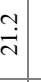 & $\stackrel{\infty}{\dot{ \pm}}$ & $\stackrel{\vec{\lambda}}{\vec{\lambda}}$ & $\stackrel{9}{2}$ & $\stackrel{n}{0}$ & $\exists$ & 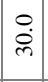 & $\stackrel{\circ}{\stackrel{+}{ \pm}}$ & $\stackrel{+}{\stackrel{D}{~}}$ \\
\hline 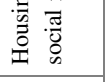 & ఏ & $\mathscr{\infty}$ & ¿্ల & & $\begin{array}{l}\mathbf{Z} \\
\mathbf{Z}\end{array}$ & $\begin{array}{l}m \\
\stackrel{n}{2}\end{array}$ & $\frac{m}{m}$ & $\stackrel{?}{\simeq}$ & 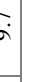 & 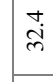 & $\begin{array}{l}0 \\
0 \\
\dot{0} \\
i\end{array}$ & $\stackrel{m}{\infty}$ & $\stackrel{\circ}{\stackrel{5}{\leftrightarrows}}$ \\
\hline 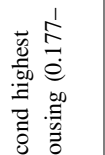 & 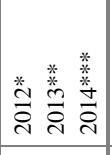 & 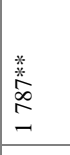 & $\stackrel{*}{\sigma}$ & & 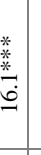 & בֶ. & 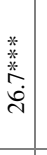 & & S. & $\stackrel{*}{m}$ & $\mid \begin{array}{l}* \\
* \\
\cdots \\
\vdots \\
\vdots \\
\vdots\end{array}$ & 落 & 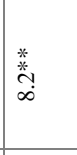 \\
\hline 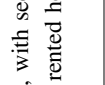 & $\stackrel{0}{\circ}$ & $\underset{\infty}{ \pm}$ & م & & $\begin{array}{l}\mathfrak{n} \\
\\
\end{array}$ & $\vec{a}$ & $\begin{array}{l}n \\
\stackrel{n}{2} \\
\end{array}$ & $\stackrel{m}{2}$ & $\stackrel{?}{\mathrm{v}}$ & $\stackrel{\infty}{:}$ & $\begin{array}{l}0 \\
\dot{\rho} \\
\end{array}$ & $\partial$ & $\begin{array}{l}0 \\
\infty\end{array}$ \\
\hline 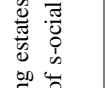 & \&્ત & $\underset{\infty}{\infty}$ & ล & & $\begin{array}{l}\dot{t} \\
\dot{\bullet}\end{array}$ & $\begin{array}{l}\infty \\
\dot{n} \\
\end{array}$ & $\vec{i}$ & $\stackrel{+}{\overrightarrow{0}}$ & $\stackrel{?}{\mathrm{v}}$ & $\begin{array}{l}\stackrel{0}{\circ} \\
\dot{q}\end{array}$ & $\begin{array}{c}\vec{j} \\
\stackrel{m}{~}\end{array}$ & $\stackrel{\infty}{=}$ & $\ddot{a}$ \\
\hline 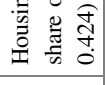 & ๖ & $\begin{array}{l}\infty \\
2 \\
2 \\
-\end{array}$ & $\hat{\sigma}$ & & $\begin{array}{l}+ \\
\dot{\sigma}\end{array}$ & $\begin{array}{l}n \\
\infty \\
\infty\end{array}$ & $\begin{array}{l}m \\
\dot{\infty} \\
\dot{\sim}\end{array}$ & $\begin{array}{c}\infty \\
\varrho \\
\varrho\end{array}$ & $\dot{a}$ & $\frac{n}{m}$ & $\begin{array}{l}n \\
m \\
m\end{array}$ & $\stackrel{n}{n}$ & $\stackrel{\circ}{\mathrm{I}}$ \\
\hline 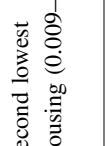 & 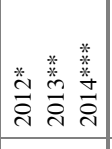 & 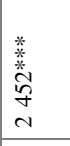 & 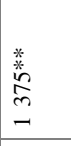 & & . & 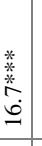 & 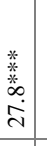 & 䊪 & 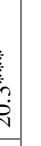 & $\begin{array}{l}\text { * } \\
\text { 絭 } \\
\dot{f}\end{array}$ & $\begin{array}{l}* \\
* \\
* \\
\stackrel{*}{*} \\
\end{array}$ & $\begin{array}{l}* \\
\cdots \\
\infty \\
\infty \\
\infty\end{array}$ & 菼 \\
\hline 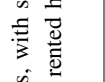 & $\stackrel{\circ}{\circ}$ & $\frac{a}{9}$ & 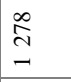 & & ذి & $\overrightarrow{0}$ & 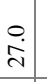 & \begin{tabular}{l|l}
0 \\
i
\end{tabular} & D. & in & $\vec{a}$ & $\underset{\infty}{+}$ & $\stackrel{2}{\sim}$ \\
\hline 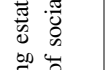 & \&্ণ & $-\infty$ & $\begin{array}{r}0 \\
-5 \\
\end{array}$ & & $\stackrel{m}{ \pm}$ & ?ִ & $\begin{array}{l}a \\
\dot{i} \\
i\end{array}$ & $\begin{array}{l}0 \\
\dot{\vec{\lambda}}\end{array}$ & 巳. & $\stackrel{0}{i}$ & $\begin{array}{l}0 \\
\dot{m}\end{array}$ & $\infty$ & $\infty$ \\
\hline $\begin{array}{l}0 \\
0 \\
0 \\
0\end{array}$ & ڤ & त है & $-\stackrel{f}{\delta}$ & & $\begin{array}{l}n \\
\varrho \\
\end{array}$ & $\stackrel{+}{\circ}$ & 芦 & $\vec{\square}$ & : & $\stackrel{ナ}{\dot{f}}$ & m. & $\hat{\check{2}}$ & $\vec{I}$ \\
\hline 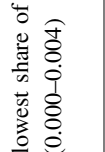 & 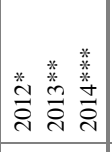 & $\stackrel{\text { F }}{*}$ & 策。 & & 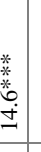 & 总 & 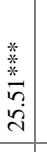 & 赵 & $\begin{array}{l}1 \\
\vdots \\
\vdots \\
\dot{b} \\
\end{array}$ & 畨 & 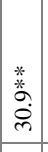 & $\begin{array}{l}\text { *. } \\
\text { 范 } \\
\infty\end{array}$ & $\begin{array}{l}* \\
* \\
\infty \\
\infty \\
\infty \\
\end{array}$ \\
\hline 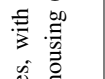 & 움 & - & I & & $\begin{array}{l}0 \\
\text { in }\end{array}$ & $\begin{array}{l}\infty \\
\stackrel{-}{-}\end{array}$ & 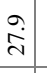 & 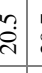 & s. & in & $\overrightarrow{\dot{m}}$ & $\vec{a}$ & $\stackrel{0}{\circ}$ \\
\hline 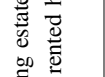 & ষ্ণ & $-\stackrel{\infty}{\infty}$ & $\vec{\sim}$ & & $\begin{array}{l}\text { 过 } \\
\end{array}$ & $\stackrel{\dot{\leftrightarrow}}{\grave{m}}$ & $\begin{array}{l}0 \\
\dot{i} \\
i\end{array}$ & $\begin{array}{l}\infty \\
\dot{i} \\
\end{array}$ & 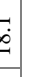 & $\vec{\sigma}$ & $\begin{array}{l}0 \\
\dot{m} \\
\end{array}$ & $\stackrel{\infty}{\sigma}$ & $\stackrel{\circ}{\circ}$ \\
\hline 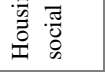 & ஃ & $\_\stackrel{\mathscr{\infty}}{+}$ & 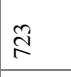 & & $\stackrel{\infty}{\leftrightharpoons}$ & $\begin{array}{l}\stackrel{\leftrightarrow}{\infty} \\
\stackrel{\infty}{*}\end{array}$ & ले & $\stackrel{\circ}{\stackrel{\infty}{\infty}}$ & 2 & $\stackrel{\circ}{\dot{m}}$ & $\begin{array}{l}\mathrm{m} \\
\mathrm{m}\end{array}$ & $\grave{\mathrm{I}}$ & $\stackrel{0}{\dot{2}}$ \\
\hline & & 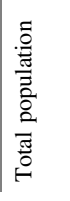 & 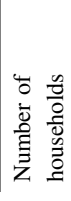 & 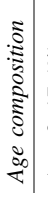 & 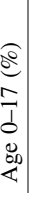 & 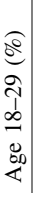 & 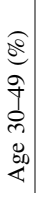 & 每 & $\begin{array}{l}0 \\
6 \\
6 \\
8 \\
0 \\
x\end{array}$ & 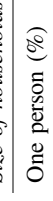 & 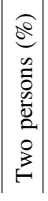 & 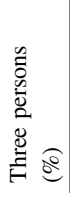 & 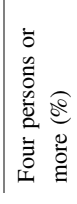 \\
\hline
\end{tabular}




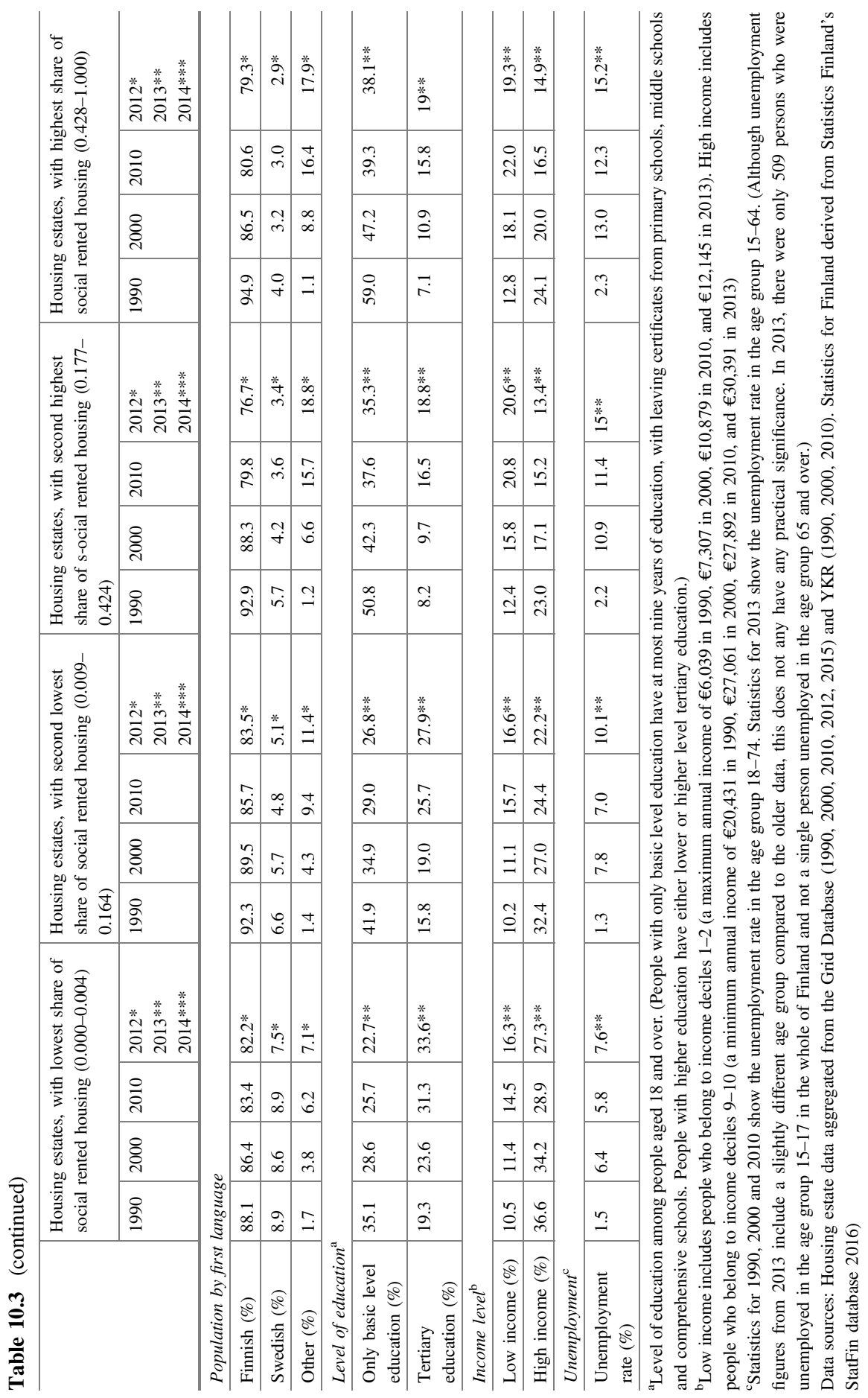


of the population of housing estates. In August 2010, the unemployment rate in Helsinki was $8.6 \%$, 26,983 people, of whom 5,149 were long-term unemployed. More striking, however, is the growing differentiation of this phenomenon within the city.

A statistical study on developments within social rental housing in Helsinki shows that during the economic upswing in the late 1990s and early 2000s, the employment rate rose until 2002, after which it has plateaued at around 52-55\%. Therefore, in a significant part of social rental housing in Helsinki, the majority of people of working age - excluding students - do not work but live on social benefits of some kind. A separate study was conducted on a high-rise suburb with a preponderance of rented housing, on the outer fringes of the metropolitan region (the suburb of Peltosaari, in the town of Riihimäki, about $100 \mathrm{~km}$ north of Helsinki). It showed that about $50 \%$ of the population of working age was either long-term unemployed or living on disability pensions of some kind.

Taking the proportion of residents over $65(15-25 \%$ on average, depending on the socio-economic level of the estate) into further account, going to work is, at present, not the default way of life in major sections of large high-rise estates in Helsinki. This makes local social life on the estates particularly significant, and the composition and community life of the different groups within the daytime population gains in importance.

A survey of the housing satisfaction of residents in the Helsinki region (Kortteinen et al. 2001, 2005) shows how feelings of insecurity and unrest have grown within the dense high-rise areas, and how these feelings co-vary with a wish to move away. A survey of those who prefer the detached suburban belt showed that the people who opt out of mixed high-rise surroundings do so in search of greater social and material homogeneity.

In 2012 a study was conducted which - for the first time in the history of the region-seemed to show that a part of the middle class was moving out of the large housing estates (Vilkama et al. 2013). The foremost local reasons for this exodus were the social conditions of life, regarded as unsafe and/or not suitable for children. In another study, we likewise found that the major causal factor producing a willingness to move away was local social disorder and feelings of insecurity (Kortteinen et al. 2001).

In 2012, we conducted a large-scale survey in the Helsinki Region, with a gross sample size of 27,000 and a response rate of $36 \%$. As the data include items on perceived social disorder, we can use it to infer the role of social housing as a determinant of local social life (see also Kemppainen 2017; Kemppainen and Kortteinen forthcoming).

Perceived social disorder was measured using six items to gauge how much the respondent had observed antisocial behaviours in the residential area; the items measured were littering or vandalism, public drunkenness, disruptive neighbours, drug abuse or trafficking, trouble-making or threatening behaviour and thefts or malicious damage. The response options ranged from never to very often. Figure 10.11 presents the unadjusted levels of a factor score variable on perceived social disorder according to the share of social housing (in quartiles). In the first 
Fig. 10.11 Perceived social disorder by share of social housing (quartiles); means of factor score variable with cluster-robust $95 \%$ confidence intervals

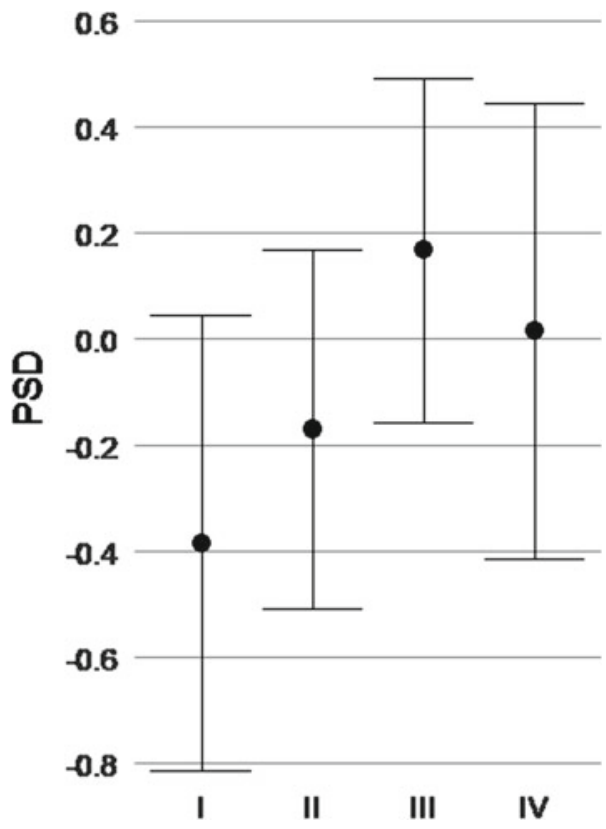

quartile - with practically no social housing - the extent of social disorder is lowest and increases linearly with increasing social housing.

Next, we ran a multilevel model of perceived social disorder with standard controls at both levels. We had to combine the variable on social housing with socio-economic and ethnic indicators due to their high correlations. The predictive power of this latent disadvantage variable — also including social housing - remains significant in the fully adjusted model. Thus, we can say that the multidimensional disadvantage of the estate - covering not only education, income and unemployment, but also ethnic heterogeneity and social housing - strongly differentiates those estates that are socially peaceful from those which are not. There is also a suggestion that this structural dimension matters in terms of local social interaction, but this topic needs more attention in the future.

Another interpretation also emerges: the small housing companies (a single house or block of houses, on average) are institutions through which the owners try to preserve and uphold the value of their greatest single asset, their dwelling. There are strong and straightforward interests that unite owners in a joint effort to achieve local social control in their houses and housing surroundings.

A separate study was conducted on the Facebook groups of the different housing areas in Helsinki. It found that the discussions among the residents of the more prosperous areas were dominated by issues having to do with social disorder and maintaining order. In the poorer housing areas (in which the problems of social disorder are most common) discussions were, surprisingly enough, linked more with swapping, sharing, recycling and cohesion (Autio 2017). Taken together, 
we propose the general hypothesis of a qualitative difference in community life in different housing types, also in the large housing estates, but this is a question that clearly demands further elaboration and research.

\subsection{Conclusion}

We started from the notion that, from an international perspective, Helsinki (and the cities of Espoo and Vantaa) has been an interesting exception in urban policy, especially concerning the development of large housing estates. An attempt has been made to use spatial social mixing (through the mixing of different tenure types) as a universal preventive policy against social disorder and segregation. Our empirical analysis seems to show that the results are mixed, or rather, that it yielded two outcomes: preventive policies seem to work as intended but, despite this, they have not been able to prevent the emergence of segregation.

Analysis of the structural development of the region gives a clear indication as to the inadequacy of the policy; attempts have been made to prevent the social drivers of segregation but, at the same time, the structural drivers have been ignored. As the structure of the public sector is based on the exceptionally strong position of the separate municipalities, problems emerge during a period of marked regional growth, as municipalities have an interest in competing for the working, tax-paying population. The municipalities on the fringes have had an advantage in this competition because of their capability to plan the predominantly detached, non-mixed housing stock, valued by the new middle classes (Vaattovaara and Kortteinen 2003). As the new wealth has moved away to the fringes, the large housing estates have declined socio-economically, and have been enriched ethnically. This differentiation is structurally produced and, as such, beyond the scope of the preventive policies pursued.

The results seem dire: although from the socio-economic perspective the spatial structure of the region is characterised by its mosaic-like pattern (based on social mixing), spatial development of deprivation is characterised by spatial concentrations, i.e. the forming of larger spatial clusters and their spatial expansion. The core areas of deprivation in the region seem to be concentrated in Helsinki and, more specifically, in and around the large housing estates in the eastern districts of Helsinki. This urban macrostructure was born during the 1990s and has prevailed and slowly intensified ever since. It would, therefore, seem that the effectiveness of the policy of spatial social mixing in the region has progressively fallen.

Two phases can be distinguished in this development. Urban differentiation in Helsinki started with a drastic structural change: with a major economic depression and the subsequent upswing, the demand for labour changed and the spatial result was seen in the socio-economic decline of the eastern sub-district of Helsinki. If the interpretation of the second phase in the development holds true, it has socio-political significance. While, given the Finnish system of governance, the housing market supply can be guided by public administration, drivers of demand 
are more difficult to control. The more heavily housing demand is guided culturally, the stronger the argument is for new political initiatives.

A plethora of research has added to the picture of the social changes taking place (Vaattovaara 1998; Vaattovaara and Kortteinen 2003; Rasinkangas 2013) as well as its ethnic dimension (Vilkama 2011), impact on students' learning outcomes and school choices (Bernelius 2013), feelings of insecurity (Kemppainen et al. 2014), prices of flats (Harjunen et al. 2014) and selective migration (Vilkama et al. 2013). In all these studies, the large housing estates in decline stand out as specific problems, starting in the early 1990s.

In Finland, poverty and social exclusion have traditionally been problems of the declining, sparsely populated rural areas. This has changed since the early 1990s, with the new challenges inherent in the rise of new urban poverty, and the growing ethnic heterogeneity. With our tradition of universal, national strategies in social policies we end up with a problem: as a nation, we have virtually no ready-made policies for the new situation. We do not have any tradition of urban or of metropolitan policies (Vartiainen 1998), and-compared to continental western Europe - we have very little experience of neighbourhood-specific initiatives.

Various debates have emerged, and these are reflected in the political initiatives and policy efforts seen in new urban development. Taken together, the emphasis of these efforts has shifted from (1) social initiatives linked to local communities, to (2) attempts at public control of the regional housing markets, to (3) physical reconstruction of the fringes of the large housing estates (new, low-rise construction in the green areas surrounding the old high-rise areas).

In the Helsinki Region - and in Finland as a whole - there is a long tradition of people-oriented initiatives targeting rootlessness, loneliness, alcoholism, antisocial behaviour and illegal drugs, all based on an assumption of improving local community life as being the basic remedy.

The Finnish Ministry of the Environment has launched specific suburban policy programmes for the development of the high-rise suburbs built in the 1960s and 1970s. These programmes began in the 1990s. Big cities and urban regions all have their own suburban developmental programmes, focused strongly on the large housing estates. In addition to Helsinki, the Finnish cities of Tampere, Turku, Jyväskylä and Oulu are involved. The work builds on partnership networks, but - in accordance with its strategy - there is a continuous search for new ideas and initiatives with the aim of also meeting social needs and problems related to low employment rates and population ageing. In addition to the above policy programmes, Finland has participated in the EU's Urban Programme (2000-2006) and with URBACT - in several social, partly neighbourhood-specific policy programmes. These programmes have functioned as an umbrella for many smaller projects, which have often been created in a decidedly local fashion.

Compared to continental Europe, however, we seem to be latecomers in these initiatives and prefer to try to find and adopt the best practices developed elsewhere. In addition, it seems that a fundamental part of these initiatives is essentially oriented towards developing local community life, seeing this as a potential 
remedy. Empirical evidence on the validity of this assumption is yet to be seen, but work continues.

Every 4 years in Finland the most important aspects of policy are concretised in the Government Programme of the Prime Minister. This also concerns housing and metropolitan policies. The attitude of the state towards the growth of the Helsinki metropolitan area has so far been somewhat negative, trying to contain the growth rather than to further encourage it. The current government has, however, launched a Metropolitan Policy Programme to identify solutions to the problems associated with land use, housing and traffic, social exclusion and to promote business and internationalisation. Multiculturalism and bilingualism are also promoted. The current letter-of-intent procedure between central government and the Greater Helsinki Area, and cooperations based on partnerships with the individual administrative sectors, will be reinforced and extended: housing production in the Helsinki region will increase from 12,000 to 13,000 apartments per year.

A characteristic feature in these new partnerships is the ethos and aim of intervening in the functioning of regional housing markets. This ethos is intertwined with the so-called 'municipal reform' by the previous government (which failed) and the attempt at a regional reform the present government (in dire difficulties). One of the aims of these initiatives is to build up bigger, more financially sustainable public units that could better manage regional development. Political tensions and contradictions abound, both nationally and regionally, and both the results and forms of implementation are yet to be seen. The main reason for the continous dispute is the increasing discrepancy with the national ideology of equality and spatial differentiation of resources combined with municipal sovereignty. The sovereignty of the municipalities enshrined in the constitution is a difficult threshold to pass and, in addition, the big cities oppose the idea of a regional administration ruling over them (Alanen 2004; Vaattovaara and Kortteinen 2003). The battle continues in an ongoing crisis where the position of the exisiting Government is seriously challenged.

The urban problems of the large housing estates have, consequently, fallen into the laps of their respective municipalities, which have tried to cope with them as best they can. The city of Helsinki, for instance, has modestly adjusted its housing policy: in 1991 the city administration still stated that 'culturally and ethnically segregated communities must be avoided' (Helsinki Immigrant Policy Proposal 1991, p. 50), but in 1999 , the aim was being reformulated to housing immigrants 'as equally as possible' (Helsinki Integration Policy, 1999, 23, in Vilkama 2006).

No demolitions have so far taken place in the Helsinki Region, excluding one rental high-rise in 2017 in the most stigmatised large housing estate of the region. Nationally, however, this is about to emerge as a major future problem. A significant share of the large housing estates built in the 1960s and 1970s has, at present, a market value that is clearly below the costs of reasonable repair, and, as a result, the small local housing companies have difficulties in procuring loans for these repairs. No solutions have been presented, except demolition.

The overall situation of the large housing estates in the Helsinki Region is better, Helsinki being the main area of growth in Finland. Attempts to counteract the 
decline have during the last ten years centred upon the idea of 'complementary construction'. Densification, support for local services and support for the socio-economic level of a housing area are all among the objectives of the policy, the predominant result of which is building low-rise and dense townhouse-type of housing into the green belt surrounding the old large housing estates. The policy aims at integrating the previously disintegrated urban fabric and, in social characteristics, resembles the mixing policies pursued in continental western Europetrying to redevelop a housing area in decline with new constructions for the middle classes. This is currently the predominant strategy in the Helsinki Region.

In a study focusing on the effects of this policy (Vilkama et al. 2013), we compared three different sites of complementary constructions, all adjacent to large housing estates and all in eastern Helsinki. The results were generally positive but contained a decidedly negative component. International discussions of the theme (Uitermark 2003; Van Beckhoven and Van Kempen 2003; Kruythoff 2003; Kleinhans 2004) seem to attach importance to the assumed social networks that are to emerge between the new and the old residents-which tend unfortunately to exhibit rather depressing outcomes. This perspective, however, overlooks the positive effect of complementary construction on the local services. In this respect, the results of the complementary construction projects were, according to our data, quite positive. The differences in the composition of the old and the new residents were, in our study, not big enough to cause the newcomers to avoid using the local services, which, as a result, gained new strength. The newcomers did, however, concentrate their living in their own micro-area within the wider neighbourhood, with very few links farther afield. To them, however, this was not a problem, but the solution: this was how they could create their own specific neighbourhood which they could safely control, in which they could settle down and feel well. On the other hand, this easily leads to the emergence of sharply demarcated, micro-geographic structures of segregation within the confines of the neighbourhood, with old and new residents both inhabiting their own areas. When this happens, one of the main aims of the legacy of the time when housing estates were built remains unfulfilled: in such a setting people do not mix, but live different realities, with very few links between them. As long as some links remain, and the local middle classes remain strong, the original objective of social order might, however, be furthered, even without local social bridging.

Taken as a whole, and compared to western Europe, the Helsinki Region seems to be a latecomer both to the decline of the large housing estates and in the remedial policies. There is a strong legacy of urban policies based on spatial social mixing. However, according to the analysis presented above, the recent decline in the large housing estates is due to reasons beyond the control of policy: structural changes in the demand for labour, socio-economic decline and migration have created a platform for the emergence local social drivers of segregation. In other words, the policy has proved inefficient and insufficient.

In addition, public discussion around this is quite difficult, partly due to the strength of the legacy of the time when housing estates were built. Questioning the traditional definitions of the common good (such as how, where and for whom the 
policy should be pursued to achieve its objectives), the discussion inevitably turns into either public moral outrage (to defend the egalitarian ethos) or professional silence-producing very little or nothing. The monopoly in the planning apparatus together with the legacy defining the public taboos are obstacles in the search for new initiatives.

Acknowledgements The authors express thanks to the Academy of Finland, Helsinki Metropolitan Region Urban Research Program.

\section{References}

Alanen JP (2004) Ihmisten arki ei tunne hallinnon rajoja-yhteistyöllä Helsingin seutu menestykseen. Sisäasiainministeriön julkaisuja, vol 13. Sisäasiainministeriö, Helsinki

Autio M (2017) Koheesio ja kontrolli. Helsingin kaupunginosat Facebookissa. University of Helsinki, Helsinki

Bernelius V (2013) Eriytyvät kaupunkikoulut. Helsingin peruskoulujen oppilaspohjan erot, perheiden kouluvalinnat ja oppimistuloksiin liittyvät aluevaikutukset osana kaupungin eri-ytymiskehitystä. Tutkimuksia, vol 1. Helsingin kaupungin tietokeskus, Helsinki

Hankonen J (1994) Lähiöt ja tehokkuuden yhteiskunta. Otatieto Oy \& Gaude-amus, Tampere

Harjunen O, Kortelainen M, Saarimaa T (2014) Best education money can buy? capitalization of school quality in Finland. Valtion taloudellinen tutki-muskeskus. Edita Prima Oy, Helsinki

Joutsiniemi A (2006) Ei-kenenkään Helsinki-Raportti esikaupungista 2005. Tampereen teknillinen yliopisto, Yhdyskuntasuunnittelun laitos, Tampere

Kemppainen T (2017) Disorder and insecurity in a residential context: a study focusing on Finnish suburban housing estates built in the 1960s and 1970s. Helsingin kaupunki, Helsinki

Kemppainen T, Kortteinen M (forthcoming) Tenure structure and local social life. In: A multi-level study on threshold effects

Kemppainen T, Lönnqvist H, Tuominen M (2014) Turvattomuus ei jakaudu tasan. Mitkä asuinalueen piirteet selittävät helsinkiläisten kokemaa tur-vattomuutta? Yhteiskuntapolitiikka Y79 (1):5-20

Kivinen O (1959) Hämeenlinnan Yleiskaava 1957. Suomalaisen kirjallisuuden kirjapaino, Helsinki

Kleinhans R (2004) Social implications of housing diversification in urban renewal: a review of recent literature. J Housing Built Environ 19:367-390

Kortteinen M, Tuominen M, Vaattovaara M (2001) Helsingin sosiaalimaantieteellinen rakenne ja pahoinpitelyrikollisuus. Yhteiskuntapolitiikka 66(4):318-328

Kruythoff H (2003) Dutch urban restructuring policy in action against socio-spatial segregation: sense or nonsense? Eur J Housing Policy 3(2):193-215

Lönnqvist H, Vaattovaara M (2004) Asuntojen hintojen kehitys pääkau-punkiseudulla: Mitä asuntojen hinnat kertovat kaupungin ajallisesta ja alueellis-esta kehityksestä. Helsingin kaupungin tietokeskus, Helsinki

Meurman OI (1947) Asemakaavaoppi. Otava, Helsinki

Perry C (1929) The neighborhood unit, a scheme of arrangement for the family-life community. Regional survey of New York and its environs, vol 7. Committee on the Regional Plan of New York and Its Environs, New York, pp 2-140

Puustinen S (2006) Suomalainen kaavoittajaprofessio ja suunnittelun kommu-nikatiivinen käänne. Vuorovaikutukseen liittyvät ongelmat ja mahdollisuudet suurten kaupunkien kaavoittajien näkökulmasta. Yhdyskuntasuunnittelun tutki-mus- ja koulutuskeskuksen julkaisuja A 34. Helsinki University of Technology, Espoo 
Rasinkangas J (2013) Sosiaalinen eriytyminen Turun kaupunkiseudulla. Tutkimus asumisen alueellisista muutoksista ja asumispreferensseistä. In, vol Tutkimuksia A 43. Siirtolaisuusinstituutti, Turku,

Schulman H (2000) Helsingin suunnittelu ja rakentuminen. In: Schulman H, Pulma P, Aalto S (eds) Helsingin historia vuodesta 1945. Edita, Helsinki, pp 13-107

Stein CS (1942) City patterns - past and future. New Pencil Points 23:52-56

Uitermark J (2003) 'Social mixing' and the management of disadvantaged neighbourhoods: the Dutch policy of urban restructuring revisited. Urban Stud 40(3):531-549

Vaattovaara M (1998) Pääkaupunkiseudun sosiaalinen erilaistuminen. Tutkimuksia, Helsingin kaupungin tietokeskus, Helsinki, p 7

Vaattovaara M, Kortteinen M (2003) Beyond polarisation versus professional-isation? a case study of the development of the Helsinki region, Finland. Urban Stud 40(11):2127-2145

Van Beckhoven E, Van Kempen R (2003) Social effects of urban re-structuring: a case study in Amsterdam and Utrecht, The Netherlands. Housing Studies 18(6):853-875

Vartiainen P (1998) Suomalaisen aluepolitiikan kehitysvaiheita. Aluekehit-ysosaston julkaisu 6/ 1998. Sisäasiainministeriö, Helsinki

Vilkama K (2006) Asuntopolitiikka ja vieraskielisen väestön alueellinen keskittyminen Helsingissä vuosina 1992-2005. Helsingin yliopiston maantieteen laitos, Helsinki

Vilkama K (2011) Yhteinen kaupunki, eriytyvät kaupunginosat? Kantaväestön ja maahanmuuttajataustastaisten asukkaiden alueellinen eriytyminen ja muut-toliike pääkaupunkiseudulla. Helsingin kaupungin tietokeskus, Helsinki

Vilkama K, Vaattovaara M, Dhalmann H (2013) Kantaväestön pakoa? Miksi maahanmuuttajakeskittymistä muutetaan pois? Yhteiskuntapolitiikka 78(5):485-497

Open Access This chapter is licensed under the terms of the Creative Commons Attribution 4.0 International License (http://creativecommons.org/licenses/by/4.0/), which permits use, sharing, adaptation, distribution and reproduction in any medium or format, as long as you give appropriate credit to the original author(s) and the source, provide a link to the Creative Commons license and indicate if changes were made.

The images or other third party material in this chapter are included in the chapter's Creative Commons license, unless indicated otherwise in a credit line to the material. If material is not included in the chapter's Creative Commons license and your intended use is not permitted by statutory regulation or exceeds the permitted use, you will need to obtain permission directly from the copyright holder. 